\title{
IDENTIFIKASI UPAYA GURU MENYEDIAKAN MEDIA PEMBELAJARAN MATEMATIKA DI SMA NEGERI 1 MANYAK PAYED Dewi Puspita Sari $^{1}$, Faisal $^{2}$
}

\author{
${ }^{1}$ Alumni Jurusan/Prodi Pendidikan Matematika IAIN Langsa \\ Email : dwi@gmail.com \\ ${ }^{2}$ Dosen Jurusan/Prodi Pendidikan Matematika IAIN Langsa \\ Email: faisal@iainlangsa.ac.id
}

\begin{abstract}
ABSTRAK
Pemakaian media pembelajaran dalam proses pembelajaran dapat membangkitkan keinginan yang baru, membangkitkan kegiatan belajar dan bahkan membawa pengaruhpengaruh psikologis terhadap siswa. Pengguna media pembelajaran pada tahap orientasi pengajaran dan akan sangat membantu keefektifan proses pembelajaran dan penyampaian pesan serta isi pelajaran pada proses belajar mengajar berlangsung. Untuk itu para guru dituntut untuk dapat menyediakan media pembelajaran yang cocok dengan materi pembelajaran pada saat proses belajar mengajar berlangsung. Rumusan masalah dalam penelitian ini adalah "Upaya apa saja yang dilakukan guru SMA Negeri 1 Manyak Payed dalam menyediakan media pembeljaran matematika". Penelitian ini bertujuan untuk mengetahui apa saja yang dilakukan guru SMA Negeri 1 Manyak Payed dalam menyediakan media pembelajaran matematika. Jenis penelitian yang digunakan dalam penelitian ini adalah deskriptif dengan pendekatan penelitian kuantitatif. Subjek yang diteliti adalah guru bidang studi matematika SMA Negeri 1 Manyak Payed yang terdiri dari 5 orang guru. Sedangkan yang menjadi objek dalam penelitian ini adalah identifikasi upaya guru dalam menyediakan media pembelajaran matematika. Instrumen yang digunakan adalah wawancara, observasi dan dokumentasi. Berdasrakan wawancara dan observasi yang telah peneliti lakukan diperoleh hasil bahwa guru-guru matematika SMA Negeri 1 Manyak Payed telah berupaya semaksimal mungkin dalam pengadaan media pembelajaran matematika dalam proses kegiatan belajar mengajar, seperti memanfaatkan barang sekitar dan lingkungan sekitar, membeli media pembelajaran jika memungkinkan, menciptakan sendiri media pembelajaran, melakukan pencarian melalui internet sampai dengan berkonsultasi dengan teman sejawat (guru-guru matematika) mengenai media pembelajaran apa yang cocok pada materi tertentu.
\end{abstract}

\section{Kata Kunci : Identifikasi, Media Pembelajaran}

\section{PENDAHULUAN}

Matematika adalah suatu proses, yang bearti bahwa dalam pembelajaran matematika siswa harus menjalani atau mengalami proses matematika. Proses matematika adalah proses belajar yang membuat konsep matematika. Agar pembelajaran lebih bermakna, maka siswa harus 
berperan sebagai subyek, artinya siswa diberi kesempatan untuk menemukan sendiri konsepkonsep yang mereka pelajari sendiri, agar kreatifitas siswa dapat berkembang. ${ }^{1}$

Mata pelajaran matematika diberikan kepada semua peserta didik mulai dari sekolah dasar sampai perguruan tinggi untuk untuk membekali peserta didik agar memiliki kemampuan berfikir logis, analitis, sistematis, kritis dan kreatif. ${ }^{2}$ Materi matematika disusun secara hierarkis artinya suatu topik matematika merupakan prasyarat bagi topik berikutnya. Hudoyo mengungkapkan bahwa karena kehierarkisan matematika itu, maka belajar matematika yang terputus-putus akan mengganggu terjadinya proses belajar. ${ }^{3}$

Guru (pendidik) merupakan faktor penting dalam proses pembelajaran, karena guru yang akan berhadapan langsung dengan peserta didik dalam proses belajar-mengajar. Melalui guru pula ilmu pengetahuan dapat ditransferkan. Guru memegang berbagai jenis peranan yang mau tidak mau harus dilaksanakannya sebagai guru.

Yang dimaksud sebagai peran adalah pola tingkah laku tertentu yang merupakan ciri khas semua petugas dan pekerjaan atau jabatan tertentu. Guru harus bertanggung jawab atas hasil kegiatan anak melali interaksi merupakan faktor yang mempengaruhi berhasil tidaknya proses belajar mengajar, dan karenanya guru harus menguasai prinsip-prinsip belajar disaping menguasai materi yang akan diajarkan. Dengan kata lain: guru harus mampu menciptakan situasi kondisi belajar yang sebaik-baiknya.

Proses pembelajaran yang ada di sekolah-sekolah Indonesia selama ini sebagian besar masih bersifat konvensional yang terpusat pada metode ceramah sehingga hanya mengoptimalkan keaktifan dan kemampuan utama guru. Pembelajaran dengan sistem ini memposisikan siswa sebagai obyek belajar yang pasif, hanya berperan sebagai penerima bahan ajar dan bukan subyek yang aktif dan berperan utuh dalm proses pembelajaran, sehingga proses pembelajaran hanya satu arah. Akbatnya, proses pebelajaran menjadi mebosankan dan siswa tidak dapat mengebangkan keterampilan dan life skill-nya.

Guru sebagai pembimbing dalam proses kegiatan belajar mengajar harus memiliki metode pembelajaran yang tepat. Sebab pada pendidikan formal semua bidang pendidikan dan bidang studi harus memanfaatkan dasar mental pada tiap anak. Hal tersebut bertujuan untuk meningkatkan kemampuan mental pada tiap anak dan juga bertujuan untuk meningkatkan kemampuan kearah kematangan dan kedewasaan dalam arti yang seluas-luasnya secara terarah dan teratur. Pendidikan dengan segala perangkatnya harus memiliki wawasan kehari mendatang. Maka dari itu guru harus pintar-pintar dalam menyesuaikan materi pelajaran dengan metode-metode yang akan dipakai. Sehingga akan tercipta suasana belajar yang efektif dan tidak monoton. Karena metode yang monoton dalam mengajar menjadikan peserta didik tertekan dan seakan ingin lari dari kelasnya.

\footnotetext{
${ }^{1}$ R. Soedjadi, Kiat-Kiat Pendidikan atematika di Indonesia, (Jakarta: Direktorat Jenderal Pendidikan Tinggi, Departeen Pendidikan Nasional, 2000), hlm. 52

${ }^{2}$ Sardiman, A.M.Interaksi dan motivasi belajar-mengajar. (Jakarta: Rajawali, 2004), hlm.23.

${ }^{3}$ Hudoyo, Belajar Matematika. (Jakarta:LPTK, 1988), hlm. 4.
} 
Saat ini dibeberapa sekolah yang berada di Kabupaten Aceh Tamiang sudah mempunyai dan memanfaatkan media pembelajaran dengan maksimal. Pemakaian media pembelajaran dalam proses pembelajaran juga dapat membangkitkan keinginan yang baru, membangkitkan kegiatan belajar dan bahkan membawa pengaruh-pengaruh psikologis terhadap siswa pengguna media pembelajaran pada tahap orientasi pengajaran dan akan sangan membantu keefektifan proses pembelajaran dan penyampaian pesan dan isi pelajaran pada saat itu.

Peneliti yakin dengan media pembelajaran yang divariasi dan dimodifikasi akan memicu kreatifitas dan potensi kritis siswa untuk aktif dalam proses pembelajaran. Dengan pembelajaran yang demikian, siswa akan mendapatkan pembelajaran yang berakna yang menyenangkan, sehingga mereka terlepas dari perasaan bosan dan beban untuk mepelajari sekian banyak materi seperti yang sering dihadapi siswa jika pembelajaran yang disapaikan bersifat monoton dan text book oriented.

Dengan pemilihan media pembelajaran yang tepat selanjutnya diharapakan berpengaruh terhadap kemajuan hasil belajar siswa. Sebagai hasil proses dari belajar mengajar, prestasi yang berhasil dicapai siswa tercermin dalam hasil evaluasi dan nilai rapor yang diperoleh siswa tiap semester. Setiap siswa diberikan pelayanan yang sama dalam proses belajar mengajar, akan tetapi hasilnya belum tentu sama antara satru anak dengan anak yang lain. Peningkatan hasil belajar dilakukan melalui proses pembelajaran dengan menggunakan media pembelajaran yang tepat, dengan menggunakan media yang tepat akan membantu guru dalam melaksanakan kegiatan pembelajaran sehingga lebih terarah dan sesuai dengan tujuan pembelajaran yang akan dicapai.

Berdasarkan latar belakang masalah tang telah diuraikan peneliti melakukan penelitian dengan judul "Identifikasi Upaya Guru Menyediakan Media Pembelajaran Matematika di SMA Negeri 1 Manyak Payed".

\section{METODOLOGI PENELITIAN}

\section{A. Lokasi Penelitian}

Penelitian ini akan dilaksanakan di SMA Negeri 1 Manyak Payed pada semester ganjil dengan pertimbangan sebagai berikut:

1. Di SMA Negri 1 Manyak Payed sudah memiliki dan memanfaatkan media pembelajaran matematika secara maksimal. hlm ini di dapat dari hasil wawancara dan observasi awal dengan guru bidang studi matematika di sekolah tersebut.

2. Terbukanya kemungkinan untuk melakukan penelitian di sekolah tersebut.

\section{B. Pendekatan dan Jenis Penelitian}

Dalam penelitian ini memakai pendekatan kualitatif dengan metode deskriptif. Metode deskriptif adalah suatu metode dalam meneliti status kelompok manusia, suatu objek, suatu kondisi, suatu sistem pemikiran, ataupun suatu peristiwa pada kejadian sekarang. ${ }^{4}$ Adapun

\footnotetext{
${ }^{4}$ Moh. Nazir, Metode Penelitian, (Bogor: Ghlmia Indonesia, 1983), hlm.54
} 
tujuan dari penelitian deskriptif ini adalah untuk mendeskripsikan upaya apa saja yang dilakukan oleh guru dalam menyediakan media pembelajaran matematika di SMAN Manyak 1 Payed.

\section{C.Subjek dan Objek Penelitian}

Subjek yang diteliti adalah guru bidang studi matematika SMA Negeri 1 Manyak Payed yang terdiri dari 5 orang guru. Sedangkan yang menjadi objek dalam penelitian ini adalah identifikasi upaya guru dalam menyediakan media pembelajaran matematika.

\section{Teknik Pengumpulan Data}

1. Wawancara

Wawancara dilakukan pada 5 orang guru matematika yang sudah memanfaatkan media pembelajaran dengan baik

2. Observasi

Observasi dilakukan untuk memperoleh gambaran riil suatu peristiwa, objek, kondisi, atau suasana tertentu untuk menjawab pertanyaan penelitian.

3. Dokumentasi

Dokumentasi dilakukan untuk mengetahui segala hlm yang terjadi pada waktu pelaksanaan penelitian dilakukan.

\section{E. Instrumen Penelitian}

Instrumen dalam penelitian ini adalah sebagai berikut:

1. Wawancara dengan guru yang menjadi subjek penelitian.

Dengan menggunakan pedoman wawancara sebagai berikut:

1) Menurut Bapak/Ibu media pembelajaran itu apa?

2) Seberapa penting media pembelajaran bagi seorang guru? Alasannya?

3) Media pembelajaran matematika seperti apa yang pernah Bapak/Ibu terapkan dikelas?

4) Menurut Bapak/Ibu apakah media pembelajaran mempengaruhi hasil belajar siswa? Alasannya?

5) Apakah media pembelajaran matematika di sekolah SMA Negeri 1 Manyak Payed sudah memadai?

6) Upaya apa yang Bapak/Ibu lakukan untuk menyediakan media pembelajaran matematika?

7) Apakah Bapak/Ibu selalu menyediakan media pembelajaran di setiap pertemuan?

8) Apa yang menjadi hambatan Bapak/Ibu dalam menyediakan media pembelajaran?

Dengan demikian pedoman sudah disusun, namun peneliti dapat mengembangkan pertanyaan wancara untuk mendalami informasi tentang upaya guru menyediakan media pembelajaran di SMA Negeri 1 Manyak Payed.

2. Observasi dalam penelitian ini adalah observasi partisipatif, dimana peneliti dalam pengamatan ikut melakukan kegiatan yang dilakukan narasumber dengan tujuan 
memverifikasi hasil wawancara yang telah dilakukan sebelunya. Observasi dilakukan oleh peneliti dengan cara melakukan pengamatan dan pencatatan mengenai bagaimana upaya guru menyediakan media pembelajaran matematika di SMA Negeri 1 Manyak Payed.

Sumber data dalam penelitian ini adalah seluruh guru bidang studi matematika yang berjumlah 5 orang.

\section{F. Langkah-Langkah Penelitian}

Dalam prosedur penelitian ini dilakukan dengan dua tahap yaitu persiapan dan pelaksanaan penelitian. Adapun langkahlangkah yang ditempuh dalam penelitian antara lain sebagai berikut:

1. Persiapan penelitian

Kegiatan persiapan proposal penelitian antara lain sebagai berikut :

a. Menyusun proposal penelitian

b. Pengajuan surat izin penelitian dari IAIN Zawiyah Cot Kala Langsa yang akan dilaksanakan di SMA Negeri 1 Manyak Payed

c. Konsultasi dengan pembimbing I dan II untuk langkahlangkah penelitian serta menetapkan metodologi penelitian yang digunakan

d. Konsultasi dengan pihak sekolah yang akan diteliti

e. Menentukan sampel penelitian yang akan dilibatkan pada penelitian yang akan dilakukan

2. Pelaksanaan penelitian
a. Melakukan wawancara
b. Melakukan observasi
c. Melakukan dokumentasi dan menarik kesimpulan dari hasil wawancara dan observasi

\section{G.Teknik Analisis Data}

Teknik analisis data yang dilakukan dalam penelitian ini adalah teknik analisis data kualitatif yaitu meliputi (1) reduksi data, (2) penyajian data, dan (3) penarikan kesimpulan.

1. Reduksi data adalah suatu proses kegiatan menyelesaikan dan menyederhanakan suatu data yang diperoleh dari awal pengumpulan data sampai penyusunan laporan penelitian.

2. Penyajian data dilakukan dalam rangka mengorganisasikan hasil reduksi dengan cara menyusun secara naratif sekumpulan informasi yang telah diperoleh dari hasil reduksi sehingga dapat memberi kemungkinan penarikan kesimpulan dan pengambilan tindakan.

3. Penarikan kesimpulan merupakan pengungkapan akhir terhadap hasil penafsiran, evaluasi dan tindakan. ${ }^{5}$

\section{PEMBAHASAN}

\footnotetext{
${ }^{5}$ S. Margono, Metodelogi Penelitian Pendidikan, (Jakarta: PT. Rineka Cipta, 2005), hlm.37-41.
} 
Berdasarkan hasil wawancara dan observasi yang telah peneliti lakukan diperoleh hasil bahwa guru-guru matematika SMA Negeri 1 Manyak Payed telah berupaya semaksimal mungkin dalam pengadaan media pembelajaran matematika dalam proses kegiatan belajar mengajar, seperti memanfaatkan barang sekitar dan lingkungan sekitar, membeli media pembelajaran jika memungkinkan, menciptakan sendiri media pembelajaran, melakukan pencarian melalui internet sampai dengan berkonsultasi dengan teman sejawat (guru-guru matematika) mengenai media pembelajaran apa yang cocok pada materi tertentu.

Media pembelajaran adalah alat-alat grafis, photografis atau elektronis untuk menangkap, memproses dan menyusun kembali informasi visual atau verbal. ${ }^{6}$ Pemakaian media pembelajaran dalam proses belajar mengajar dapat membangkitkan keinginan dan minat yang baru, membangkitkan motivasi dan rangsangan kegiatan belajar, dan bahkan membawa pengaruh psikologis terhadap siswa. ${ }^{7}$

Dalam proses belajar mengajar, dua unsur yang amat penting adalah metode mengajar dan media pembelajaran. Pemilihan salah satu metode mengajar tertentu akan mempengaruhi jenis media pembelajaran yang sesuai, meskipun masih ada berbagai aspek lain yang harus diperhatikan dalam memilih media, antara lain tujuan pembelajaran, jenis tugas dan respon yang diharapkan siswa kuasai setelah pembelajaran berlangsung, dan konteks pembelajaran termasuk karakteristik siswa. ${ }^{8}$ Salah satu fungsi utama media pembelajaran adalah sebagai alat bantu mengajar yang turut mempengaruhi iklim, kondisi dan lingkungan belajar yang di tata dan diciptakan oleh guru.

Media pembelajaran menurut Kemp \& Dayton dalam Arsyad dapat memenuhi tiga fungsi utama apabila media itu digunakan untuk perorangan, kelompok, atau kelompok pendengar yang besar jumlahnya, yaitu : ${ }^{9}$

1. Memotivasi minat atau tindakan

Media pembelajaran dapat direalisasikan dengan teknik drama atau hiburan. Hasil yang diharapkan adalah melahirkan minat dan merangsang para siswa atau pendengar untuk bertindak (turut memikul tanggung jawab, melayani secara sukarela, atau memberikan subangan material). Pencapaian tujuan ini akan memperngaruhi sikap, nilai, dan emosi.

2. Menyajikan Informasi,

Media pembelajaran dapat digunakan dalam rangka penyajian informasi dihadapan sekelompok siswa. Isi dan bentuk penyajian bersifat amat umum, berfungsi sebagai pengantar, ringkasan laporan, atau pengetahuan latar belakang. Penyajian dapat pula berbentuk hiburan, drama, atau teknik motivasi

3. Memberi Intruksi

Media berfungsi untuk tujuan instruksi di mana informasi yang terdapat dalam media itu harus melibatkan siswa baik dalam benak atau mental maupun dalam bentuk aktivitas yang nyata sehingga pembelajaran dapat terjadi. Materi harus dirancang secara lebih sistematis dan

\footnotetext{
${ }^{6}$ Azhar Arsyad, Media Pembelajaran, (Jakarta : Rajawali Pers, 2013), hlm.3

${ }^{7}$ Ibid, hlm.19

${ }^{8}$ Ibid.

${ }^{9}$ Ibid, hlm. 23
} 
psikologis dilihat dari segi prinsip-prinsip belajar agar dapat menyiapkan instruksi yang efektif. Di samping menyenangkan, media pembelajaran harus dapat memberikan pengalaman yang menyenangkan dan memenuhi kebutuhan perorang siswa.

\section{KESIMPULAN DAN SARAN}

\section{A. Kesimpulan}

Berdasarkan hasil wawancara dan observasi yang telah peneliti lakukan diperoleh hasil bahwa guru-guru matematika SMA Negeri 1 Manyak Payed telah berupaya semaksimal mungkin dalam pengadaan media pembelajaran matematika dalam proses kegiatan belajar mengajar, seperti memanfaatkan barang sekitar dan lingkungan sekitar, membeli media pembelajaran jika memungkinkan, menciptakan sendiri media pembelajaran, melakukan pencarian melalui internet sampai dengan berkonsultasi dengan teman sejawat (guru-guru matematika) mengenai media pembelajaran apa yang cocok pada materi tertentu.

\section{B. Saran}

Setelah memaparkan hasil penelitian, penulis merasa harus memberikan beberapa saran. Adapun saran-saran tersebut adalah :

1. Diharapkan kepada para guru SMA Negeri 1 Manyak Payed hendaknya menggunakan media pendidikan secara baik dan benar karena merupakan salah satu alat dan sumber belajar yang paling efektif untuk meningkatkan prestasi belajar Pendidikan Agama Islam, dan dapat membangkitkan gairah belajar siswa, sehingga guru disini dituntut untuk dapat menyelaraskan antara metode dan media yang digunakan dalam pembelajaran dan juga guru harus mampu menggunakan serta mengoperasikan beberapa macam media yang sudah ada serta dapat membuat media yang mungkin belum tersedia di dalam kelas yang bersifat praktis, tahan lama, efisien, ekonomis yang dapat dijangkau oleh sekolah.

2. Bagi kepala sekolah hendaknya lebih mengawasi lagi dalam setiap proses pembelajaran, apakah proses belajar mengajar sudah efektif atau belum? Karena kepala sekolah merupakan motoring atau manajering dari sekolah tersebut. Dan juga kepala sekolah perlu memperbaiki media-media pembelajaran yang sudah mengalami penurunan, dan juga perlu menambah media, alat dan sumber belajar yang lain yang dibutuhkan sekolah mengingat pengaruh media pembelajaran terhadap prestasi siswa sangat besar.

3. Untuk siswa hendaknya lebih aktif dan kreatif dalam mengikuti pembelajaran matematika. Siswa jangan hanya sebagai orang yang diajar melainkan siswa harus dapat memposisikan dirinya sebagai orang yang belajar. Untuk itu belajar tidak harus ada seorang guru di dalam kelas, akan tetapi media pembelajaran dapat menggantikan guru sebagai sumber balajar, dan yang lebih penting lagi siswa jangan hanya berkompeten dalam aspek kognitifnya saja, aspek efektif dan psikomotorik juga harus meraih prestasi dari masyarakat.

\section{DAFTAR PUSTAKA}

Albary, Dahlan. et.al. 2011. Kamus Ilmiah Populer. Surabaya: Arkola 
Alma, Buchlmma. et.al. 2008. Guru Profesional: Menguasai Metode dan Terampil Mengajar. Bandung: Alfaberta

A.M. Sardiman. 2004. Interaksi dan Motivasi Belajar-Mengajar. Jakarta: Rajawali

Arsyad, Azhar. 2013. Media Pembelajaran. Jakarta: Rajawali Pers

Dadang, Supriatna. 2009. Pengenalan Media Pembelajaran. Disajikan untuk Bahan ajar untuk

Diklat E Training PPPPTK TK dan PLB (pengenalan-media-pembelajaran.PDF-Adobe Reader)

Departemen Pendidikan Nasional. 2008. Standar Kompetensi Mata Pelajaran Matematika Sekolah Menengah Pertama dan madrasah Tsanawiyah. Jakarta: Depdiknas

Djamarah, Syaiful Bahri. et.al. 1997. Strategi Belajar Mengajar. Jakarta: PT Rineka Cipta

Hamalik, Oemar. 1989. Media Pendidikan. Bandung: Citra Aditya Bakti

Hudoyo. 1998. Belajar Matematika. Jakarta:LPTK

Margono, S. 2005. Metodelogi Penelitian Pendidikan. Jakarta: PT. Rineka Cipta

Nazir, Moh. 1983. Metode Penelitian. Bogor: Ghlmia Indonesia

Poerwadarminto. 2008. Kamus Besar Bahasa Indonesia Pusat Bahasa. Jakarta: Gramedia Pustaka Utama

Purwanto, Ngalim. 2000. Psikologi Pendidikan. Bandung: Remaja Rosdakarya

Rosyidi, Abdul Wahab. 2009. Media Pembelajaran. Malang: UIN-Malang Press

Soedjadi, R. 2000. Kiat-Kiat Pendidikan atematika di Indonesia. Jakarta: Direktorat Jenderal Pendidikan Tinggi, Departeen Pendidikan Nasional

Sadiman, dkk. 1990. Media Pendidikan. Jakarta: Rajawali

Sadiman, Arief S. dkk. 1990. Media Pendidikan pengertian, pengembangan, dan pemanfaatannya. Jakarta: Rajawali

Suherman, Erman. 2003. Strategi Pembelajran Matematika Kontemporer. Malang: UPI

Sukiman. 2012. Pengembangan Media Pembelajaran. Yogyakarta: PT Pustaka Insan Madani

Suparlan. 2006. Guru Sebagai Profesi. Yogyakarta: Hikayat Publishing

Suyitno, Amin. 2006. Dasar-dasar dan proses pembelajaran matematika I. Dipergunakan untuk perkuliahan Program Studi Matematika: Jurusan Matematika FMIPA Universitas Negeri Semarang 